\title{
Outsourcing Regulation: Analyzing Nongovernmental Systems of Labor Standards and Monitoring
}

\author{
Dara O'Rourke
}

A range of new nongovernmental systems for advancing labor standards and enforcement have emerged over the last 5 years. This article comparatively assesses these multistakeholder systems of codes of conduct and monitoring, discusses their underlying models of regulation, and proposes a set of criteria for evaluating their effectiveness, including their legitimacy, rigor, accountability, and complementarity. Critical issues are raised about the transparency of existing initiatives, independence of monitors, convergence of standards, and dynamics among nongovernmental regulation, unions, and state enforcement. The article concludes by arguing that with increased transparency, improved technical capacities, and new mechanisms of accountability to workers and consumers, nongovernmental monitoring could complement existing state regulatory systems.

\section{Introduction}

Recent accounts of the proliferation of "sweatshops" and deplorable conditions of work in both developing and industrialized countries call into question the effectiveness of existing systems of governance over labor practices (Chan, 2001; Block, Roberts, Ozeki, \& Roomkin, 2001; Compa, 2001; Jeffcott \& Yanz, 1999). Nongovernmental organizations (NGOs), unions, consumers, and even some firms-for different reasons-criticize current systems of labor standards and enforcement for their opaque processes, limited scope and coverage, weak capacities of regulators, limited leverage over recalcitrant firms, and general ineffectiveness (Nadvi \& Wältring, 2001). These critiques have grown louder in the face of new challenges of regulating global firms and their mobile supply chains. Traditional labor regulations and the government-implemented monitoring and enforcement systems on which they depend appear simply to be outpaced by changes in the global economy.

A number of strategies have emerged in response to these perceived limitations of labor regulation. These range from efforts to strengthen the capacity of 
Table 1. ILO Core Conventions

\begin{tabular}{llcc}
\hline Core Principle & \multicolumn{1}{c}{ Convention } & $\begin{array}{c}\text { Countries } \\
\text { ratifying }\end{array}$ & $\begin{array}{c}\text { U.S. } \\
\text { ratified }\end{array}$ \\
\hline $\begin{array}{l}\text { Freedom of association } \\
\text { and collective } \\
\text { bargaining }\end{array}$ & $\begin{array}{l}\text { Freedom of Association and Protection of the } \\
\text { Right to Organize, Convention No. 87, 1948 }\end{array}$ & 141 & No \\
\cline { 2 - 4 } $\begin{array}{l}\text { Right to Organize and Collective Bargaining, } \\
\text { Convention No. 98, 1949 }\end{array}$ & 152 & No \\
and compulsory labor & Forced Labour, Convention No. 29, 1930 & 161 & No \\
\cline { 2 - 4 } $\begin{array}{l}\text { Abolition of Forced Labour, Convention No. } \\
\text { Elimination of } \\
\text { discrimination in the } \\
\text { workplace }\end{array}$ & $\begin{array}{l}\text { 105, 1957 } \\
\text { Equal Remuneration, Convention No. 100, 1951 }\end{array}$ & 156 & Yes \\
\cline { 2 - 5 } $\begin{array}{l}\text { Discrimination (Employment and Occupation), } \\
\text { labor }\end{array}$ & $\begin{array}{l}\text { Convention No. 111, 1958 } \\
\text { Minimum Age, Convention No. 138, 1973 }\end{array}$ & 157 & No \\
\cline { 2 - 5 } & Worst Forms of Child Labour, Convention No. & 132 & Yes \\
\hline
\end{tabular}

Source: International Labour Organisation. Retrieved from

http://www.ilo.org/public/english/standards/norm/whatare/fundam/

local labor inspectorates to developing international systems of labor regulation that operate above the level of the nation-state, such as attempts to institutionalize a "social clause" in the World Trade Organization (WTO) (Hughes \& Wilkinson, 1998; Maskus, 1997) and efforts to advance a set of "core standards" for labor protections (Lee, 1997) through declarations of the International Labour Organization (ILO). The ILO core standards are outlined in Table 1.

This article focuses on yet another strategy gaining momentum over the last several years, involving the development and implementation of nongovernmental systems of labor regulation. These nongovernmental regulatory strategies seek to function along the lines of outsourced production: regulating firms across their supply chains through "voluntary" standards (sometimes developed in cooperation with NGOs and unions), internal and external monitoring systems, and new sanctions and incentives.

In order to advance these strategies, nongovernmental organizations are taking on activities that were previously the sole purview of state and international regulatory bodies. Participants are working to fill holes in traditional government regulation and to transform the nature of existing regulation. These initiatives involve new forms of collaboration, new roles for nongovernmental organizations, new responsibilities of firms, and new responses from local and national government authorities. In many ways, these systems are in flux, as is global labor regulation more broadly (Arthurs, 2001).

Nongovernmental systems of labor regulation are expanding extremely rapidly across industries and regulatory arenas-from garments to shoes, toys, 
forest products, oil and gas, mining, chemicals, coffee, electronics, and even tourism (Herrnstadt, 2001; Gereffi, Garcia-Johnson, \& Sasser, 2001; Wick, 2001; Cashore, 2002; Utting, 2002). However, to date very little rigorous analysis has been conducted on the impacts and implications of these potentially transformative institutions. And the analysis that has been conducted has been highly contentious, either advocating programs or dismissing them out of hand.

Advocates tout these initiatives as more flexible, efficient, democratic, and effective than traditional labor regulation (see, for instance, Bernstein, 2001), whereas critics conversely assert that nongovernmental regulation is a corrupt attempt to free industry from the last vestiges of state regulation and union organizing (see, for instance, Justice, 2001). Proponents argue that these systems can supplement and even support government regulation, but opponents assert that nongovernmental regulation implicitly challenges the legitimacy and efficacy of state regulation. Some fear nongovernmental systems of regulation will preempt or "crowd out" worker organizing efforts and the current role of unions, whereas others believe these systems can support worker empowerment and participation in shop-floor negotiations. Some believe monitoring and certification will provide consumers with a false sense that problems have been solved and will demobilize international labor and environmental campaigns, but others see the information generated by nongovernmental regulation as key to transforming how we produce, consume, and regulate around the world.

This article seeks to critically and constructively engage this heated debate and assess new systems of nongovernmental labor monitoring and regulation. Based on interviews with staff of each of the leading initiatives in the United States and Europe; interviews with multinational managers and advocacy organizations; a review of the existing literature and program documents; and direct evaluation of monitoring activities in China, Korea, Indonesia, and Mexico, this article details key efforts at nongovernmental labor regulation, explains how these systems function, describes the challenges they face, and evaluates their effectiveness in improving labor practices.

The article begins by describing and evaluating the key nongovernmental labor regulatory programs in the United States and Europe: the Fair Labor Association, the Worldwide Responsible Apparel Production certification program, Social Accountability International, the Ethical Trading Initiative, the Fair Wear Foundation, the Workers Rights Consortium, private firm internal monitoring initiatives, and independent investigations and organizing by NGOs. The article comparatively assesses these systems, discusses their different models of regulation, and proposes a set of criteria for evaluating their effectiveness. The article concludes by arguing that nongovernmental regulation can be effective under certain conditions-when monitoring and remediation are technically rigorous, publicly transparent, politically legitimate, and accountable to key stakeholders (in particular to workers and consumers).

Before discussing the details of these programs, it is worth exploring briefly 
why nongovernmental regulatory systems are emerging and what they seek to achieve.

\section{The Emergence of Nongovernmental Regulation}

Much of the existing literature on "privatized" regulation explains nongovernmental regulation as a response to two connected trends: the weakening of national governments (due to globalization, neoliberal movements to shrink the state, or simply the failure of state bureaucracies) and the strengthening of multinational corporations (Strange, 1996; Evans, 1997; Schmidt, 1995; Cutler, Haufler, \& Porter, 1999). States are turning to "market-based" and private voluntary strategies as an alternative or a supplement to traditional regulation (Haufler, 2001). Firms support this trend as a step towards enlightened "self-regulation."

Some governments clearly view nongovernmental regulatory strategies as more "flexible" and "responsive" regulatory mechanisms (Ayres \& Braithwaite, 1992) that can supplement overworked and underresourced state labor agencies (Nadvi \& Wältring, 2001; Reinicke, 1998). Market-based mechanisms and public disclosure systems are also increasingly popular as methods of regulation (Braithwaite \& Drahos, 2000). Nonstate, market-driven systems (Cashore, 2002) are attractive to governments, as they can take up some of the demands placed on state agencies, an especially pressing concern in developing nations. By enlisting the energies of multinational firms, private sector auditors, and NGOs in monitoring labor performance, governments can potentially increase compliance without increasing state budgets or staff (Nadvi \& Wältring, 2001).

Firms are "voluntarily" participating in or leading these programs because of significant new pressures to improve their labor, environmental, and social performance. Brand-sensitive firms are joining nongovernmental initiatives or creating their own codes of conduct and monitoring schemes in response to direct pressures and demands from activists. Codes and monitoring systems are viewed as a strategy to reduce reputational risks in the marketplace (Conroy, 2001). One bad supplier can significantly damage a firm's reputation and, in turn, its sales and stock value. Firms with suppliers in countries with weak enforcement systems or a poor track record on child labor are viewed with suspicion by informed stakeholders. These firms thus need independent means of establishing their "good" performance (Nadvi \& Wältring, 2001, p. 28). Firms may also be advancing these programs as a strategy to preempt stricter state regulation and to undermine the legitimacy of the state and unions in regulating labor issues.

Codes of conduct and monitoring systems also offer several advantages over traditional regulatory regimes in the eyes of firms. These systems build on some of the central organizational principles of contemporary globalizationoutsourcing production, monitoring, and continuous improvement-and so can advance a form of regulation that multinational firms find compatible with business strategies (Wach \& Nadvi, 2000; Sabel, 1994). Supplier firms in devel- 
oping countries increasingly see compliance with new labor standards as a prerequisite to entry into global supply chains. Today contractors have to perform not only to world-class standards on quality and price but also on labor and environmental standards. Meeting these new standards can mean greater market access, closer ties to global buyers, and in some cases price premiums (Conroy, 2001; Nadvi \& Kazmi, 2001).

The development of nongovernmental regulatory systems, however, has also been motivated by public perceptions of the failures of state and intergovernmental regulation and by growing demands from civil society actors for new mechanisms of corporate accountability. One surprising trend in the emergence of nongovernmental regulation has been the role and support of NGOs that have historically been extremely suspicious of market mechanisms, weakening state roles, and privatized regulation. However, for groups interested in strengthening the enforcement of labor standards, nongovernmental regulation is attractive as a supplemental system of monitoring and enforcement. Increasingly influential NGOs are thus advancing market-oriented, nongovernmental standards and monitoring systems as a supplement to state regulation in countries where it is ineffective and as a new point of leverage over firms operating globally (Cashore, 2002; Conroy, 2001).

Consumers are in many ways at the root of these processes. Increasingly aware consumers are demanding more information on the products they buy and on systems to help them avoid "sweatshop" products. Elliott and Freeman (2001) report that over $80 \%$ of consumers polled in the United States are willing to pay more for products that are made under "good" conditions, over 75\% report feeling a moral obligation to help improve workers' conditions, and over $90 \%$ agree that countries should be required to maintain minimum standards for working conditions. Consumers in particular seek to avoid "bad" companies, such as those implicated in "sweatshop" production. A recent poll by Environics International (1999) found that $51 \%$ of Americans reported "punishing" a firm for bad social performance in the previous year. Codes of conduct, monitoring systems, and labeling schemes have emerged as means to provide consumers with the information needed to buy their desired level of workplace conditions and to send market signals to firms to improve their performance (Liubicic, 1998; Freeman, 1994).

\section{Outsourcing Labor Regulation}

Nongovernmental systems of labor monitoring and regulation are both more diverse and "messier" than traditional regulatory approaches. These initiatives go beyond the past procedures of government stipulation of fixed rules and standards, government monitoring and enforcement, and judicial review (Arthurs, 2001; Lipschutz, 2000; Reinicke, 1998). Nongovernmental initiatives involve multiple actors in new roles and relationships, experimenting with new processes of standard setting, monitoring, benchmarking, and enforcement. In a number of regards, 
these new nongovernmental regulatory strategies are following in the footloose steps of global production processes. As networks of production extend along increasingly complex supply chains, interested stakeholders are exploring systems of dispersed but interconnected regulation over production. These emerging regulatory systems are almost as complex as the supply chains they seek to monitor. They include chains of standard setters, layers of monitoring and enforcement, and competing systems of incentives and action.

A critical shift in this process is the move from factory-centered, state regulation focusing on individual sites of production to supply-chain and "brand" regulation focusing on multiple actors in a production chain. This shift involves establishing systems of accountability and management of performance across factories and nations. Outsourced regulation attempts to create a network of regulators, involving multiple stakeholders along global supply chains. Whereas traditional regulation involves a national government establishing standards and policing performance, outsourced regulation involves NGOs and firms in standard setting and monitoring, with the ILO core standards and local laws as minimum standards. Whereas traditional regulation uses state sanctions to enforce standards, outsourced regulation relies largely on "market" sanctions-either through interfirm purchasing decisions or NGO consumer campaigns. Whereas government regulation is hierarchical and arms-length, outsourced regulation is networked at multiple levels and engaged with multiple actors in the supply chain.

Nongovernmental regulation is actually a diverse family of regulatory strategies, many of which are currently in competition. Even the terminology used to describe these systems is contested. In this article, I use internal monitoring to refer to monitoring conducted by brands and retailers, external monitoring to refer to monitoring conducted by third-party organizations, and verification to refer to independent evaluations (not paid for by those being monitored) of the results of codes and monitoring systems. Detailed descriptions of existing programs can help elucidate these different models.

\section{Codes of Conduct}

Nongovernmental regulatory systems are based on voluntary standards, usually embodied in codes of conduct, which specify norms and rules by which to evaluate factory performance. These standards are sometimes quite specific, detailing precise rules of action, while in other cases presenting only general principles of good practice (Douglas, 2001; Braithwaite \& Drahos, 2000). In both the United States and Europe, NGOs are now at the forefront of efforts to develop entirely new institutions (some nongovernmental, some public-private partnerships) to advance codes and to define institutional procedures to monitor compliance. Increased pressure from labor and human rights groups has motivated a growing number of multinational corporations to adopt codes of conduct and to submit to some form of external monitoring. ${ }^{1}$ 
Codes related to labor standards were originally quite diverse (OECD, 1999; Varley, 1998; Diller, 1999; Compa \& Hinchliffe-Darricarrere, 1995) but now appear to be converging around the ILO core standards and basic principles regarding the protection of health and safety, wages and hours, and treatment of women. ${ }^{2}$ Although the general range of issues addressed in these systems is fairly similar (van Tulder \& Kolk, 2001), the details of codes can vary considerably. Table 2 presents a summary of the codes of conduct advanced by the four primary U.S. monitoring systems. Key debates continue around issues such as freedom of association, wages (minimum vs. prevailing vs. "living"), and the scope of "nondiscrimination" clauses.

Systems for implementing and evaluating code compliance are obviously critical to the credibility of these codes. To these ends, a number of initiatives have emerged over the last several years to foster the implementation, monitoring, and verification of codes.

\section{Firm Internal Compliance Monitoring}

Many large brands and retailers have developed procedures for monitoring supplier compliance with their newly created codes of conduct. The Gap, for instance, has a vendor compliance department with over 100 staff responsible for monitoring the implementation of the company's code of conduct throughout its global supply chain. Levi's, Disney, Walmart, H\&M, and other companies have established similar programs. These systems can either be extensions of existing supply chain management programs - simply adding labor, human rights, and environmental concerns to current systems for evaluating quality, timeliness, price, and so on-or they can involve entirely new systems for internal monitoring and evaluation. Some companies are asking their quality control and purchasing staff to take on code compliance as an additional task, but others are hiring dedicated staff to conduct precertification audits of contractors and ongoing assessments of code compliance.

Nike was one of the first companies in the apparel and footwear industries to develop an internal compliance division. In 1992 Nike established a code of conduct on labor and environmental practices for its network of suppliers (now over 900 factories around the world employing over 650,000 workers). Supplier compliance with the code is monitored through a program of internal evaluation conducted first by Nike staff and then reviewed by external accounting, health and safety, and environmental consulting firms. Nike has developed internal monitoring tools, such as its SHAPE (Safety, Health, Attitude of Management, People Investment, and Environment) audit and MESH (Management, Environment, Safety, and Health) program, that allow the company to integrate the evaluation of labor and environmental issues into broader management practices and training (Nike, 2002). MESH resembles the ISO 14000 management auditing program, though it seeks to go further by evaluating actual factory performance. Nike now 


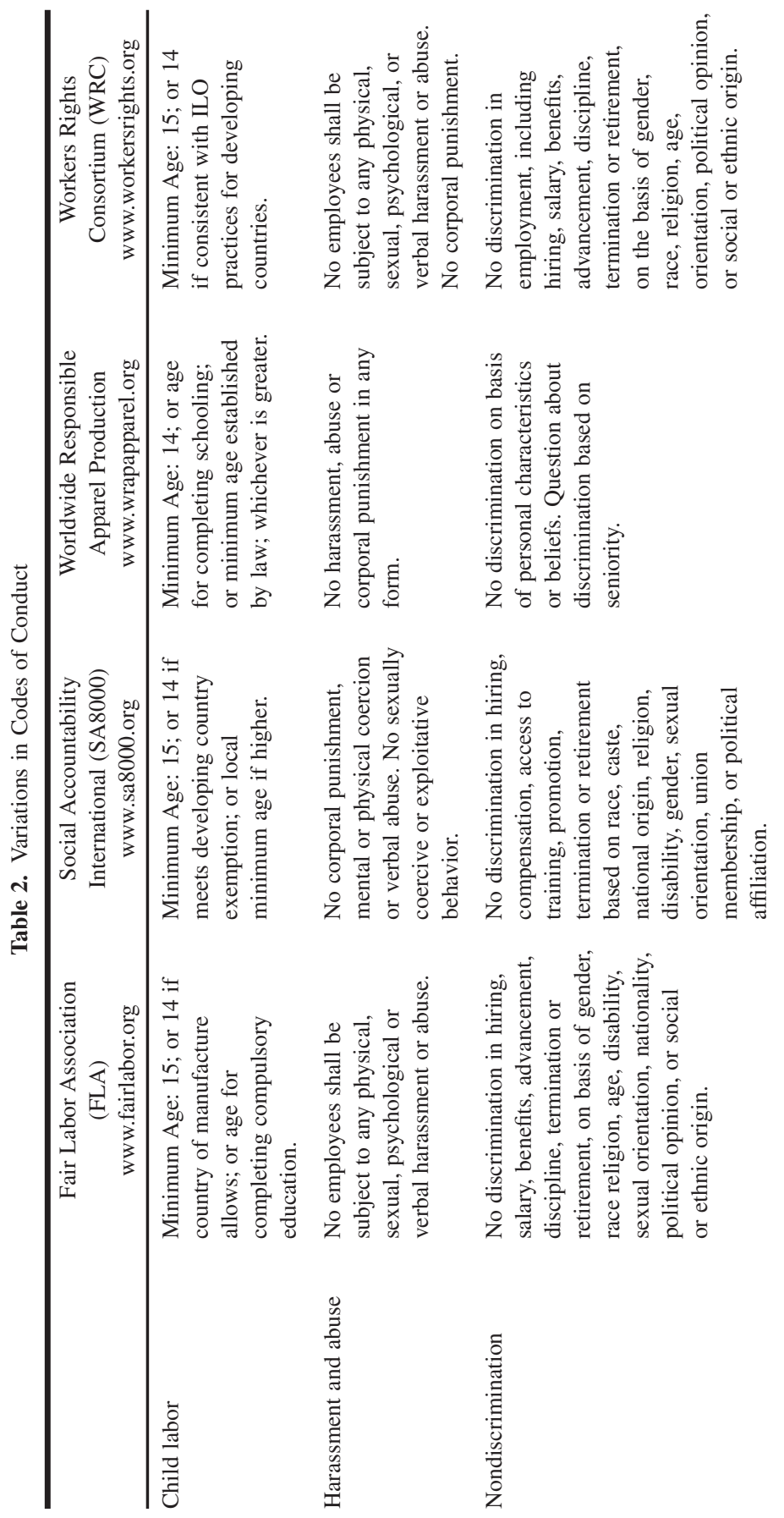



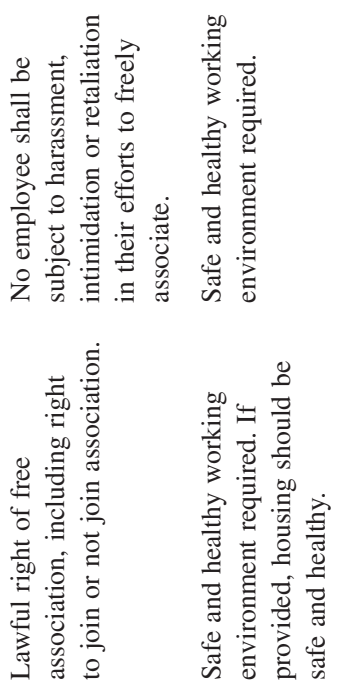
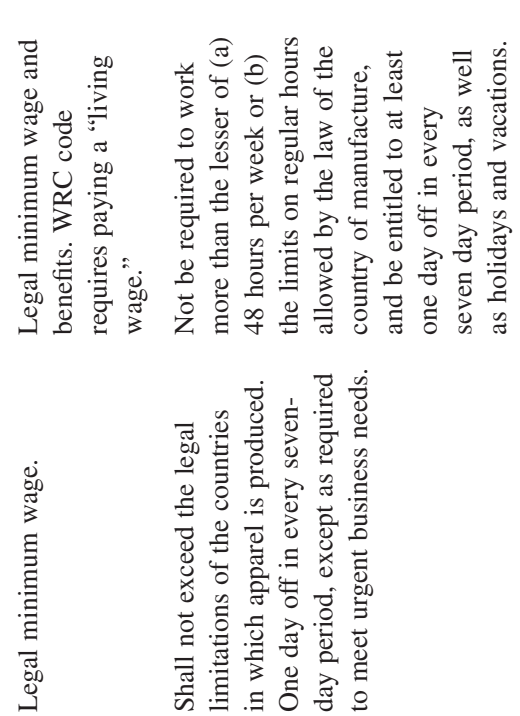

兽

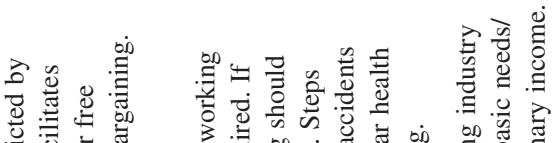

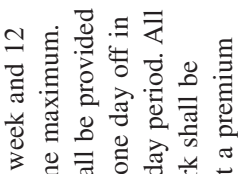
总 总 :

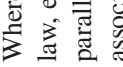

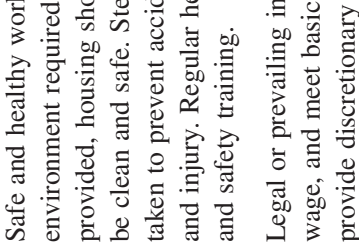

疍苟

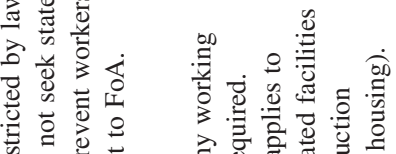

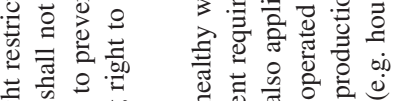

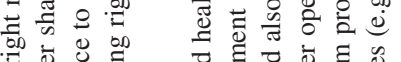

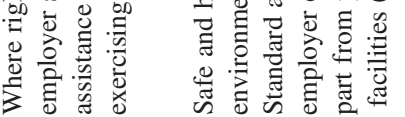
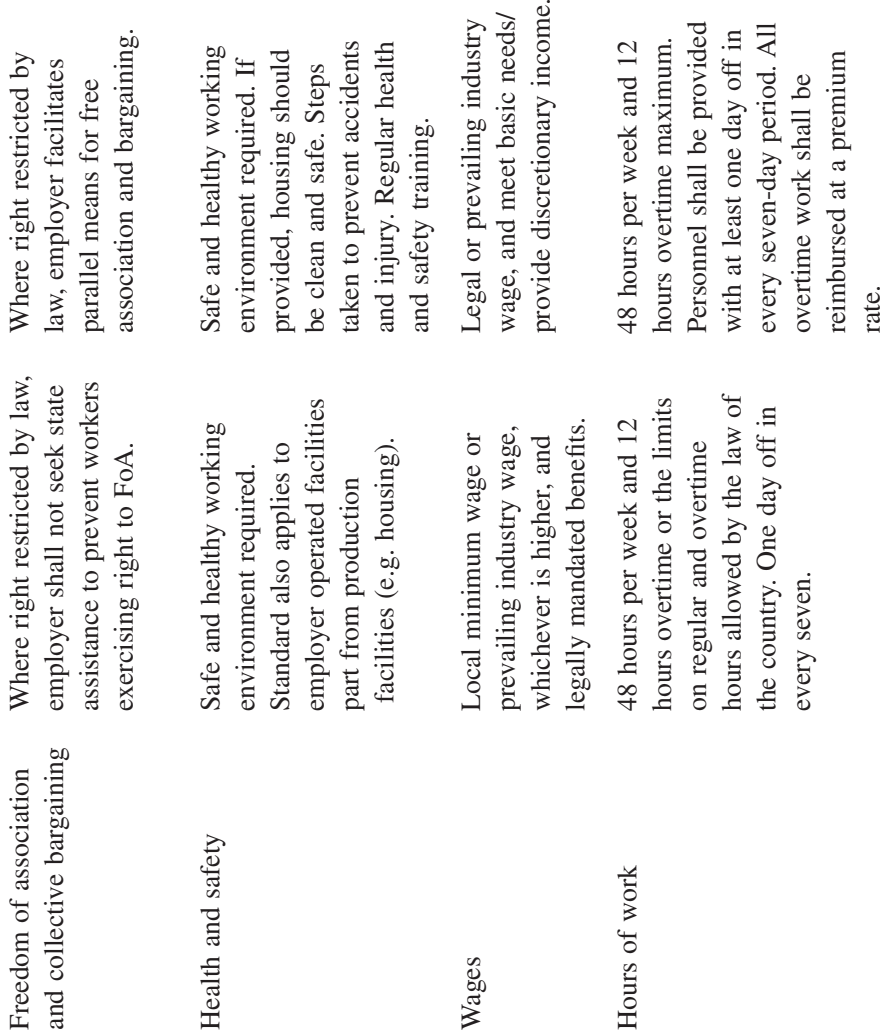

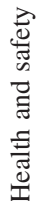

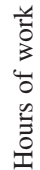


has over 80 staff members who monitor labor and environmental conditions in the company's contractor factories. Reebok and adidas, Nike's main competitors, along with many other prominent footwear and apparel firms, have established similar programs that combine in-house assessment with audits by consulting firms. Reebok, for instance, has instituted a worldwide "Human Rights Production Standards Factory Performance Assessment" system, and adidas has created a "Standards of Engagement" for labor practices and health, safety, and the environment for all its subcontractors (interviews conducted with staff of Nike, Reebok, and adidas, 2000, 2001).

Through these auditing tools, companies such as Nike, Reebok, and adidas now regularly rate their subcontractors for environmental and labor performance. In the case of Nike, points are assigned for performance in a wide range of categories, with double weight given to labor and environmental performance rankings. Subcontractors are then told how they rate against other subcontractors in the same country. High scorers often garner more lucrative orders, whereas low scorers risk losing contracts. Nike bases these labor and environmental programs on long-standing quality control management systems for evaluating and ranking subcontractors. Requirements to improve labor conditions simply extend the scope of commitments agreed to in the code of conduct and subcontractor memorandum of understanding. Providing some evidence that this effort is earnest, Nike has cancelled a handful of contracts because of poor performance and an unwillingness of factories to change.

It is hard to determine how much improvement firm-led codes of conduct and monitoring programs have achieved. Little research exists on the impacts of codes and self-monitoring on actual workplace conditions. Firms naturally assert that these systems respond effectively and sufficiently to labor concerns. Many companies continue to argue that they alone (perhaps with the assistance of a consulting firm) have the knowledge and ability to solve labor problems. However, judging by press reports, neither activists nor the general public put much credence in corporate self-evaluation and monitoring (Connor, 2001a). Based on recent cases in which codes and monitoring have been used for public relations rather than for improving labor conditions, many stakeholders criticize voluntary codes and internal monitoring for their vulnerability to corporate manipulation (O'Rourke, 2002).

\section{External Monitoring and Certification}

Growing public awareness and further activist pressure have led to a recent profusion of programs in the United States and Europe to establish standardized codes of conduct and systems of monitoring that are conducted by accredited third-party auditors. Three major initiatives of this type have emerged in the United States: the Fair Labor Association (FLA), Social Accountability International (SAI), and the Worldwide Responsible Apparel Production (WRAP) certi- 
fication program. Each of these programs has a code of conduct informed largely by ILO core standards and a system in place for accrediting external organizations to monitor compliance with their codes. A small army of monitors, including large accounting firms, professional service firms, and small nonprofit organizations are emerging to provide these third-party monitoring services (Bartley, 2001). ${ }^{3}$ These external monitoring systems differ in key procedures for auditing (who conducts the monitoring and how), certification (whether a factory or a brand is certified), and reporting (what is publicly disclosed). Table 3 highlights differences in these systems.

\section{Fair Labor Association (FLA)}

The Fair Labor Association (FLA), convened originally by the Clinton administration in 1996 as the Apparel Industry Partnership (AIP), is both the oldest and most controversial of current initiatives to establish monitoring and verification. The FLA originally focused only on the apparel and footwear industries but has recently expanded to cover other industries producing university-logo goods. As of November 2002, the FLA consisted of 13 footwear and apparel firms, several nongovernmental organizations, and about 170 university affiliates. $^{4}$

The FLA has developed a "Workplace Code of Conduct and Principles for Monitoring," accredits monitors, reviews audits, and reports on audit results. The FLA advances a monitoring system that requires companies seeking "certification" to first inspect (internally) at least half of their factories during the first year and all of their factories during the second year. Companies are then required to hire external monitors to evaluate at least $30 \%$ of their supplier factories during the first 2-3 years of the certification process, and 5\% annually thereafter. ${ }^{5}$ Over 2000 internal audits have been conducted, and the FLA expects to complete 300 external audits by the end of 2002 .

The FLA model has come under fire from a number of unions, NGOs, and student activists for being overly controlled by industry (Benjamin, 1998; Maquila Solidarity Network [MSN], 2001a). Critics pointed out that firms could select and directly pay their own monitors, have a say in which factories were audited, and only disclose summaries of auditing results. Student activists have also criticized the FLA for failing to advance a living wage and for not supporting union and women's rights sufficiently.

The board of the FLA responded to these criticisms in April 2002 by announcing sweeping changes in the program's external monitoring and disclosure procedures (Fair Labor Association [FLA], 2002). The FLA is now taking much more control over external monitoring, with the FLA staff selecting factories for evaluation (from a sample of "high risk" firms), choosing the monitoring organization, requiring that inspections be unannounced, and receiving all audit reports directly. The FLA will then work with the brand and factory in a remediation process and will publicly disclose summaries of the results of the audits and 


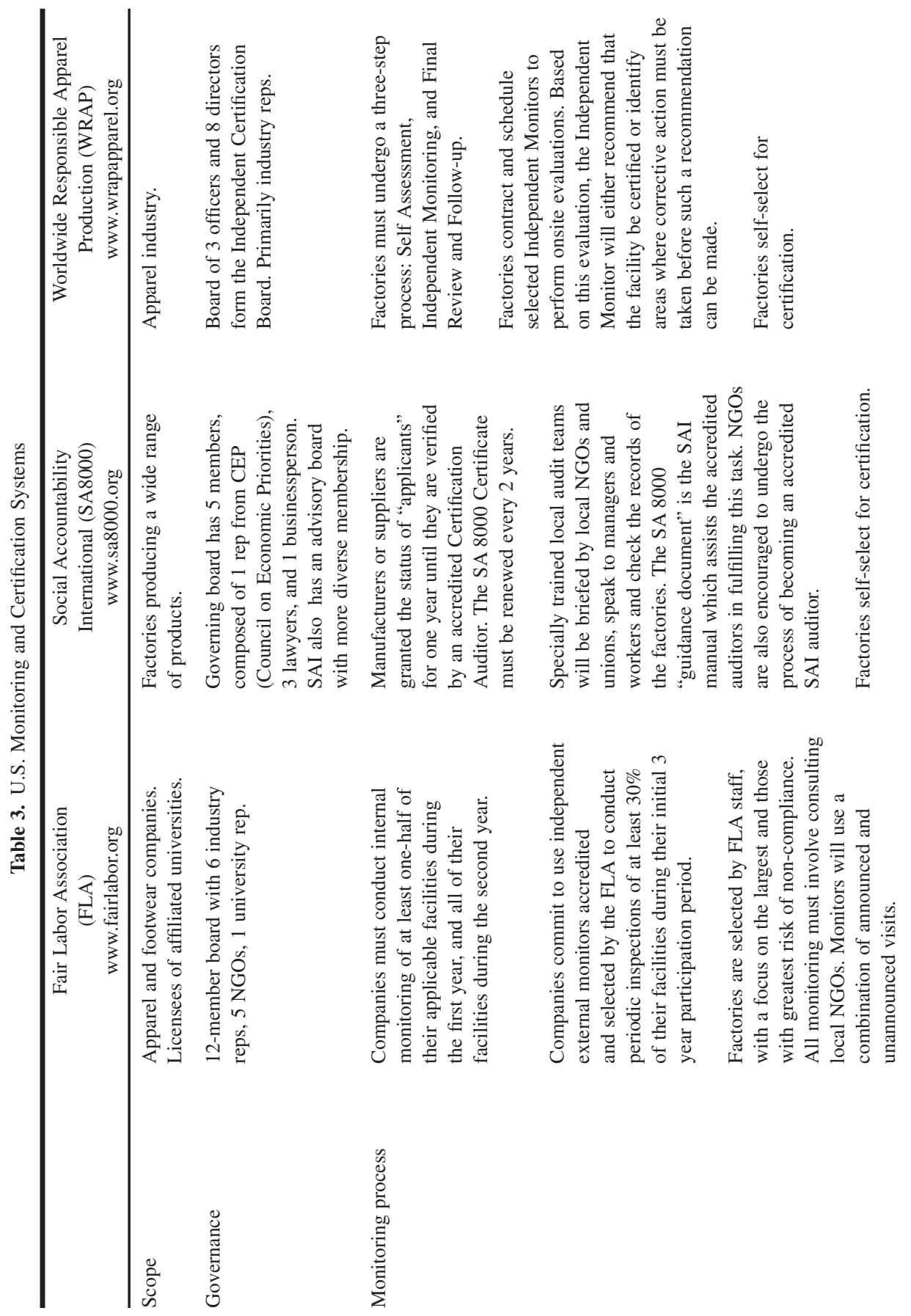



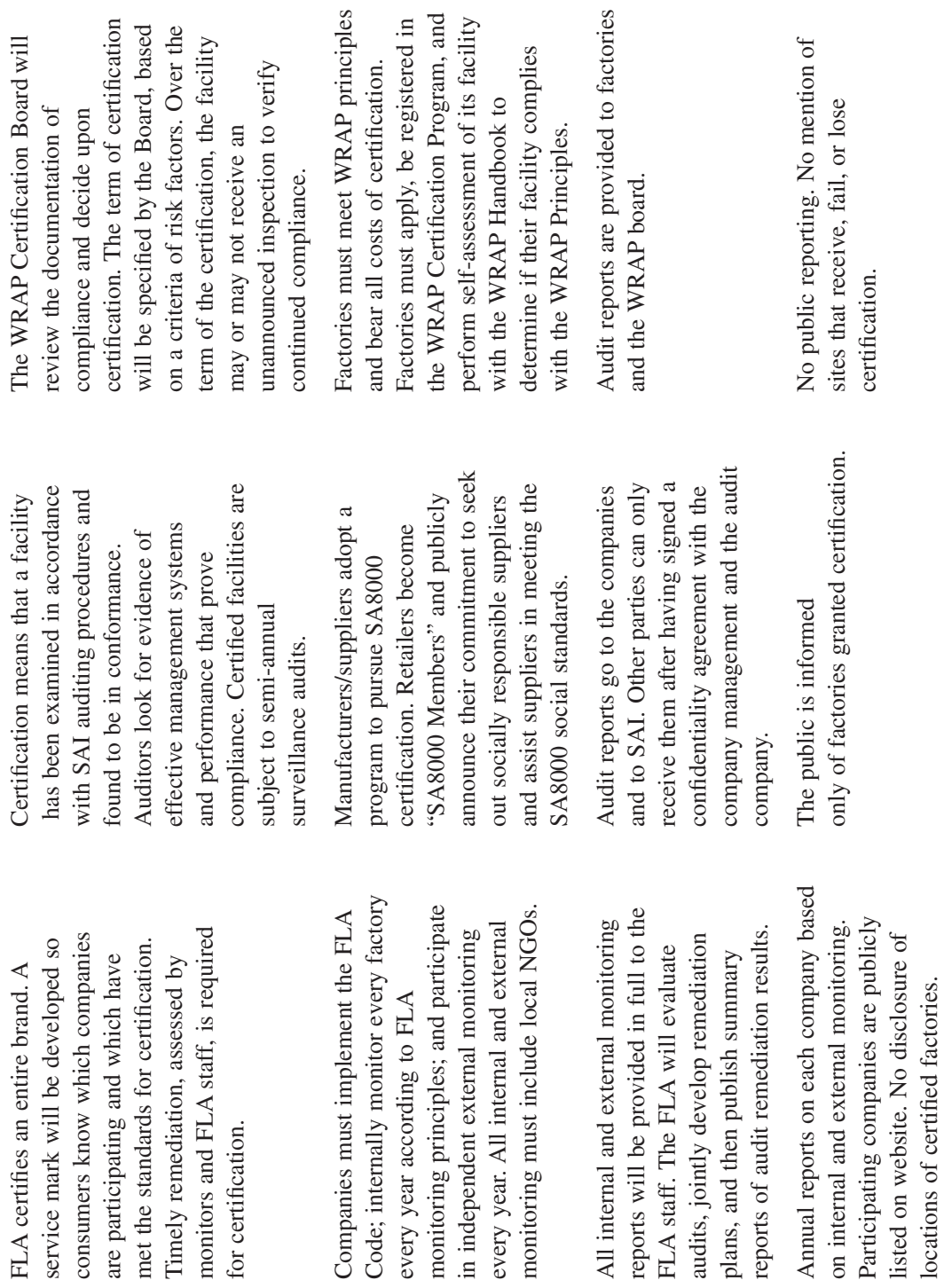

Ũ⿱艹⿹勹巳

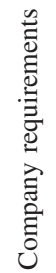

:

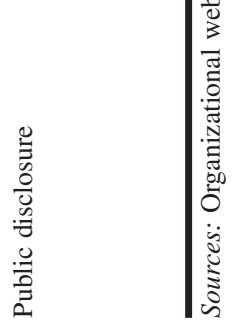


remediation efforts. FLA staff conduct their own follow-up inspections to verify that remediation has occurred. The FLA is also expanding its external complaint procedures and internal management systems reviews of brands.

\section{Social Accountability International (SA8000)}

SA8000, a voluntary workplace standard patterned on the International Organization of Standards system (e.g., ISO 9000 and ISO 14000), was created in 1997 by the Council on Economic Priorities (a U.S. NGO). The SA8000 standard is administered by Social Accountability International (SAI), with an advisory board made up of representatives from multinational firms, international unions, and NGOs. SAI seeks to motivate factories as well as member brands in a wide range of industries to implement the SA8000 code of conduct and to be audited by accredited auditors. SAI is responsible for accrediting these auditing firms; for conducting trainings for auditors, factory managers, and workers on the standards; and for publishing a list of factories meeting the SA8000 standard.

The SA8000 system differs from the FLA in a number of regards, most notably on the issues of wages, worker representation, and certification. SA8000 may be interpreted to include the requirement that factories pay workers a "living wage," or what SAI refers to as a "basic needs" wage, as opposed to the FLA's weaker requirements to pay the prevailing wage (see Table 2). SA8000 also requires firms to "facilitate parallel means of independent and free association and bargaining" in countries where it is not possible to form free trade unions (such as China). Both of these provisions remain highly controversial, as it is not clear, for instance, exactly what would qualify as effective parallel means of representation in countries such as China. SA8000 also includes a section on management systems that requires policies and procedures to ensure ongoing compliance with the standard.

SA8000 also differs in that it certifies manufacturing facilities, not brands or retailers. The idea behind this system is that brands and merchandisers will seek out factories that have received SA8000 certification, as they look to ISO 9000 certification to verify quality standards. SAI is also developing a Signatory Member program, ${ }^{6}$ which requires members to move their supplier factories toward SA8000 compliance and to periodically report progress in meeting these plans.

SAI discloses lists of certified facilities and their locations but does not publicly disclose which facilities have lost their certification or were rejected in their applications. One hundred fifty factories in 27 countries had been certified under SA8000 as of September 2002. Of these, 28 were apparel and textile firms. It is not clear whether any of the Signatory Members' affiliated facilities have received SA8000 certification.

A number of concerns have been raised about the SAI strategy. Critics have argued that it is impossible to "certify" that any factory is in compliance with the 
SA8000 standard based on a 1-day audit, once per year. Others point out the limitations of a voluntary, factory-centered initiative that has to date certified only 150 factories out of at least 100,000 factories producing for the U.S. market. The SA8000 auditing procedures have also been criticized by NGOs for a perceived corporate bias and weak controls on the quality of monitors (Labor Rights in China [LARIC], 1999). No NGOs have been accredited as auditors within the SAI system. Auditing is conducted by professional service firms and quality testing firms.

\section{Worldwide Responsible Apparel Production (WRAP)}

The Worldwide Responsible Apparel Production (WRAP) program might be viewed as industry's version of external monitoring and certification. WRAP was developed in 1998 by the American Apparel Manufacturers Association (which recently became the American Apparel and Footwear Association [AAFA]) and began certifying factories in June 2000. WRAP's board members include major apparel brands, such as Vanity Fair Corporation, Sara Lee, Kellwood, and Gerber Childrenwear. The WRAP Certification Board consists of individuals primarily from the private sector, with a nominal claim that the majority of its members are not directly affiliated with the apparel industry (MSN, 2001a).

Like the FLA and SA8000, WRAP has created its own code of conduct that it calls the "WRAP Principles." The twelve WRAP Principles include common standards for child and forced labor and workplace and environmental protections. However, WRAP also contains unique requirements for customs compliance and drug interdiction efforts that support tighter security controls over suppliers and shipments. The WRAP Principles are widely viewed as the weakest standards of any of these systems and the least transparent monitoring and certification program (MSN, 2002).

WRAP certifies factories not brands, similar to SA8000. The WRAP Certification Board accredits firms to be external monitors of manufacturing facilities. WRAP has accredited 10 firms as monitors to date (MSN, 2002), again primarily professional service firms, such as ITS, Global Social Compliance (formerly PwC), BVQI, and Cal-Safety. Certification of facilities is valid for 1 year, and factories are required to undergo self-assessment and to submit to external monitoring. External monitors submit Facility Monitoring Reports to the WRAP Certification Board, which then reviews each report and makes the decision for or against certification. Upon certification, facilities may or may not be subject to unannounced inspections. As of April 2002, approximately 200 factories had been certified by WRAP to meet its code (personal communication with L. Doherty, WRAP).

WRAP has been criticized by a range of stakeholders for its perceived industry bias and low level of public transparency. WRAP does not disclose the names or locations of certified or audited factories, and it has not disclosed any audits to date. WRAP also lacks any NGO or civil society participation in monitoring 
or verification, or a system for workers or NGOs to register complaints regarding certified factories. All audits are preannounced and conducted by firms paid directly by the factories being audited.

\section{European Monitoring Initiatives}

A number of monitoring initiatives are also emerging across Europe. The Ethical Trading Initiative (ETI) was initiated in England in 1998. ETI is an alliance of companies, NGOs, and trade unions working to "identify and promote good practice in the implementation of codes of conduct of labour practice, including the monitoring and independent verification of the observance of code provisions." (ETI, 2001) ETI was established explicitly as an experimental, learning initiative, designed to help identify and disseminate information on how best to implement labor codes that benefit workers in global supply chains. ETI has conducted pilot projects in a number of countries, including apparel factories in Sri Lanka. These pilots are key to the ETI strategy, as they generate information on issues such as how to monitor for child labor, how to evaluate the quality of 1day audits, how different actors can contribute to auditing, how best to establish worker complaint systems, and so on. ETI reports the findings of its pilots and company internal auditing to member organizations but not to the general public.

The Dutch Clean Clothes Campaign established the Fair Wear Foundation (FWF) in 1999 (after 5 years of discussions and negotiations on code issues) to work with associations of small- and medium-sized enterprises to oversee the implementation of a standard code of conduct. FWF requires company monitoring of their supply chains, with independent verification and effective worker complaint procedures. The foundation plans to certify companies that have a system in place to gather evidence on factory conditions in their supply chains. FWF is responsible for verifying that the code is being implemented in a percentage of each firm's factories. FWF has conducted pilot studies in India, Poland, Romania, and Indonesia to test its monitoring and verification procedures.

\section{Independent Investigations and Verification}

A major critique of many of these external monitoring systems has been that auditors in these programs are paid directly by the brands or factories being monitored. This potential conflict of interest raises concerns that monitoring is not "truly independent" and thus may miss or cover up problems in factories. As mentioned, the FLA board has responded to these critiques by approving a change in the process for hiring monitors so that firms will not be allowed to directly pay monitors. Nonetheless, an additional layer of nongovernmental regulation has emerged to respond to this credibility concern. This independent monitoring and verification involves NGOs, unions, and private individuals monitoring firm performance without direct payment from those with a stake in auditing results. There 
are several institutionalized versions of independent monitoring in the United States and Europe.

\section{Worker Rights Consortium (WRC)}

The Worker Rights Consortium (WRC) was developed in 1999 by the United Students Against Sweatshops (USAS) in cooperation with the Union of Needletrades, Industrial and Textile Employees (UNITE); the American Federation of Labor-Congress of Industrial Organizations (AFL-CIO); and a number of human rights, labor, and religious NGOs. The WRC had 108 college and university members as of November 2002 and focuses primarily on factories producing apparel with university logos.

The WRC employs three broad strategies: (1) inspections of factories from which the WRC has received worker complaints; (2) proactive inspections in countries with patterns of poor practice and worker organizing efforts; and (3) information disclosure requirements. The WRC does not certify company compliance with a code of conduct, conduct systematic monitoring, or accredit monitors. Instead, the WRC encourages (but does not require) participating universities to adopt codes of conduct that closely resemble the WRC's model code, which includes strong provisions for a living wage, women's rights, and recognition of worker's rights to freedom of association. The WRC requires member universities to commit to broad public disclosure and to develop mechanisms to verify information reported by companies and their suppliers.

The WRC's goal is to ensure that factories that produce university-branded apparel comply with a base code of conduct and, in particular, with rights to freedom of association and collective bargaining. The WRC also seeks to educate workers themselves about university codes so that workers may report code violations to local NGOs or the WRC. The WRC aims to work collectively with its university affiliates, the licensee corporations (the manufacturers), and local NGOs to correct problems that have been identified. The WRC's investigative efforts rely on collaboration with local NGOs and activists; personnel from either the WRC, its board, or affiliated university members; and labor and human rights experts.

To date, the WRC has investigated conditions at four factories. ${ }^{7}$ It makes all of its factory investigation reports public. The WRC is also developing a database of manufacturing facilities (www.workersrights.org/fdd.asp), which allows anyone with Internet access to search by factory name, location, or university affiliate. The WRC is increasingly focusing on remediation processes, working with universities and buyers (usually the brands) and workers' organizations to negotiate solutions to problems raised by workers, with the hope that there will be some "ripple effect" to other factories in these regions.

The WRC is of course not without its detractors. It has been criticized (and

publicly opposed) by a number of firms and university administrators. ${ }^{8}$ Opponents 
have accused the WRC of representing a "gotcha" model of monitoring, more focused on identifying problems and embarrassing firms than on resolving problems (Nike refuses to comply, 2000). And the WRC's in-depth inspection system has been criticized for having a limited scope and coverage.

\section{Related "Global" Initiatives}

There are several other initiatives that while not explicitly focused on codes and monitoring, are potentially supportive or complementary to nongovernmental regulation. The Global Reporting Initiative (GRI), for instance, is a project to advance globally applicable guidelines for voluntary self-reporting of economic, environmental, and social performance of firms. The GRI is working to set a global standard for corporate reporting, creating a system analogous to financial reporting procedures for environmental and social issues. This standard, and broader efforts for corporate disclosure, could strengthen and help to standardize existing codes and monitoring systems.

The United Nations (UN) is also advancing voluntary codes and reporting systems through the Global Compact initiative, created by the UN General Secretary in 2000. The Global Compact is in the words of the UN "not a regulatory instrument or code of conduct, but a value-based platform designed to promote institutional learning. It utilizes the power of transparency and dialogue to identify and disseminate good practices based on universal principles" (Global Compact, 2001). Towards this end, the Global Compact asks companies to commit to respecting nine principles, including respect for human rights, labor rights (basically the ILO core standards), and the environment, and to report annually on their progress on advancing these principles. The Global Compact and GRI now work together, with GRI reports qualifying for Global Compact annual reporting. It should be noted, however, that neither initiative requires external or independent monitoring or verification of any kind. These initiatives remain essentially self-reporting and disclosure systems.

\section{Models of Outsourced Regulation}

The diversity of current codes and monitoring systems has led to both confusion and debate about the benefits and costs of nongovernmental regulatory strategies. Versions of nongovernmental regulation range from individual factories paying to be certified, to multinational brands internally monitoring their contractor factories, to multistakeholder initiatives accrediting third-party organizations to inspect factories, to independent NGOs inspecting factories individually or in coordination with worker campaigns. In these different forms of outsourced regulation, the substance, scope, implementation, participation, and reporting of inspection results can vary considerably. And more importantly, these 
systems also vary in their underlying models for changing labor practices in global supply chains.

Modern governance systems, of course, involve complex arrangements and interactions between public and private actors. However, traditional labor regulation, now often disparaged as "command-and-control" policy, might be thought of as largely a state-centric, local "policing" model of governance. Clear, fixed rules are established, and government inspectors police compliance with these standards to advance a kind of "interventionist" regulation (Knill \& Lehmkuhl, 2002).

Nongovernmental labor regulation represents a significantly different model of regulation, involving multiple stakeholders participating in standard setting, monitoring, and sanctions (or incentives). And as we have seen, among nongovernmental regulatory initiatives there are different underlying models. The FLA, SAI, and WRAP are all firmly centered around enlisting market drivers for improved supplier performance. WRAP and SAI advance a system based largely on factory certification. These initiatives certify that management systems are in place to guarantee acceptable performance in individual factories. Certification provides a stamp of approval that is designed to attract customers to self-selecting factories. WRAP and SAI tap into the motivations of individual factories seeking to connect into socially concerned (and presumably high-value) buyers, as factories are audited only if they ask (and pay) for the evaluation. These systems involve an advanced a form of "privatized regulation" (Knill \& Lehmkuhl, 2002; Utting, 2002).

The FLA advances market pressures by creating a supply chain policing system involving multiple stakeholders. This advances a kind of "collaborative regulation" or "regulated self-regulation" (Ayres \& Braithwaite, 1992; Teubner, 1983) that depends on top-level commitment to the code from a brand or retailer, both internal and external monitoring of suppliers, and participation of NGOs in providing legitimacy to the system. The FLA also provides information to buyers that can be used to influence supply chains.

The WRC is building essentially a "fire alarm" model of regulation (McCubbins \& Schwartz, 1984) that focuses on creating new mechanisms of accountability for both firms and government agencies by gathering information from workers and local organizations and then helping them to organize to win demands. Alarms are triggered through complaints from workers and local NGOs, which motivate WRC inspections. Factories and the brands purchasing from them are targeted through this bottom-up process. The WRC then puts pressure on brands to improve conditions and, at the same time, works to facilitate worker empowerment and organizing to negotiate improvements. Supporting freedom of association and collective bargaining are primary goals of the WRC.

So these different emerging systems create a spectrum of new regulatory processes: from purely "privatized" regulation (firm internal monitoring and 
WRAP), to more "collaborative" regulation (SAI, FLA, and ETI), to more "socialized" regulation (FWF and WRC).

\section{Evaluating Nongovernmental Regulation}

There is, unfortunately, virtually no public data available to analyze how well these systems of regulation are currently performing. Developing measures to evaluate nongovernmental regulation remains a critical area for future research. However, there is some evidence from programs in the United States and from sporadic reports from monitoring initiatives around the world that can help us begin to evaluate nongovernmental regulation.

For instance, more than 60 companies have signed agreements with the U.S. Department of Labor to conduct factory monitoring, and hundreds of other companies are conducting monitoring on their own. Private monitoring firms conducted over 10,000 audits of garment shops in Los Angeles alone in 1998, which is about 10 times the number carried out by state and federal authorities (Esbenshade, 2000, p. 5). This monitoring is generally unsystematic, with little oversight, no transparency, no sanctions for poor monitoring, and potential conflicts of interest of monitors. This would appear at first blush to be a failure of nongovernmental regulation. However, somewhat surprisingly, this third-party monitoring has actually led to increased levels of compliance. As Esbenshade reports:

Monitoring has significantly raised the rate of compliance in the industry. The rate of compliance rose 20\% between 1994 and 1996, in part due to the proliferation of monitoring. In 1998, DoL statistics indicate that the rate of violations in non-monitored shops is twice as high as in monitored ones. However, the data also demonstrate that while monitoring helps, it has far from solved industry's problems. Fifty six percent of monitored shops are still violating labor laws. (2000, p. 5)

Many of the initiatives described above are still too new to evaluate fully. The FLA has only recently begun its external monitoring program. The FLA has, however, established a complaint response system and is developing remediation strategies when problems are identified. For instance, in response to a third-party complaint submitted by Nike, the FLA sent a team to the Dominican Republic to assess a labor dispute at the BJ\&B cap factory in January 2002. Workers alleged freedom of association violations when 20 workers were fired from the facility after having signed a petition to form a union. Within 24 hours of receiving the complaint, FLA-participating company compliance staffs were on location and conducted unannounced factory visits; off-site interviews with workers; and a review of facility payroll, personnel, and timecard records. Staff of the WRC also participated in this inspection. The dispute was resolved within several weeks.

As mentioned, SAI has certified 150 factories to meet the SA8000 standard. SAI staff assert that member companies have conducted over 2,000 audits of 
supplier factories in preparation for these certifications. SAI has also conducted a number of auditor, supplier, and worker trainings around the world. To date, over 1,100 people have taken SAI's supplier training course in 19 different countries. SAI is also working with the International Textile, Garment, and Leather Workers Federation to support workers in 12 countries across Latin America, Africa, and Asia on increasing worker involvement in workplace standards and monitoring systems.

One of the problems of evaluating these systems is their limited transparency. The FLA and SAI currently do not publish data on the factories audited, findings of audits, or changes over time in performance. WRAP has yet to publicly disclose the number of factories it has certified, improvements it has made in factory operations, or even how the organization is working to influence suppliers and buyers.

The WRC, on the other hand, makes all of its reports public. The first-of the Kukdong garment factory (now known as Mexmode) in Puebla, Mexico-is touted as a major success, as the process has supported improvements in factory conditions and pay (workers have won a series of pay raises since the WRC investigation), the formation of an independent union, and the signing of a collective bargaining agreement (one of the first in a Mexican Maquiladora factory). The WRC has also recently completed an investigation in Indonesia that has led to the remediation of existing problems and an agreement to recognize multiple unions in the factory.

\section{Limits to Nongovernmental Regulation}

There are obviously a number of weaknesses and challenges to making these different regulatory systems effective. Nongovernmental monitoring faces many of the same mundane challenges as traditional government monitoring and enforcement, including coverage, corruption, incentives of monitors, training and capacity of inspectors, and so on. The long and mobile nature of apparel supply chains, which has strained traditional regulation, makes nongovernmental monitoring extremely challenging. The Gap alone sources from 4,000 factories in 55 countries; Disney is estimated to source from over 30,000 factories and Walmart from even more (Wach \& Nadvi, 2000).

The ability of firms to move production quickly among factories and to hide behind multiple layers of ownership makes systematic inspections extremely difficult. ${ }^{9}$ A number of critics have raised concerns that nongovernmental monitoring involves visits to factories that are too infrequent to evaluate normal dayto-day operations. "Parachuting" monitors are able to identify the most obvious problems but may miss many of the largest issues and are not around long enough to actually solve problems (O'Rourke, 2002). Critics surmise, quite reasonably, that NGOs will not be able to duplicate national labor inspectorates, as they cannot cover the full extent of factories (Justice, 2001). 
There are also concerns about how many workers these systems can actually reach. Many markets - such as informal sector production, business-to-business commodities, and production for domestic consumption in developing countries-lack ethically inclined consumers. As Pearson and Seyfang (2002) have argued, voluntary codes and monitoring primarily influence "enclaves" in the global economy rather than applying universally. Nongovernmental regulatory systems focus on workers in first-tier suppliers and often large-scale factories. They rarely reach down to informal-sector or home-based workers (Lee, 1997).

Codes and monitoring also entail fairly complex technical and social issues. Consulting and accounting firms and NGOs will need extensive training to adequately play the role of industrial hygienists or experts on wages and hours. Counting on private actors or NGOs to provide these skills assumes that they, or the firms being monitored, will assume the cost of training and conducting rigorous inspections.

Even if nongovernmental regulation can overcome these critical implementation challenges, a number of deeper concerns remain. Critics fear that nongovernmental regulation will provide public relations cover to brands, may confuse consumers with a proliferation of labels and certifications, and may have unintended negative impacts on workers in developing countries (Liubicic, 1998). Another critical concern is that nongovernmental regulation may be helping to privatize governmental regulation. Some critics warn that companies are controlling these processes, co-opting NGOs by changing them from watchdogs to "partners" and undermining strong local laws and unions (Justice, 2001, p. 6). Having NGOs play the role of regulators may also ultimately undermine traditional regulatory processes (Nadvi \& Wältring, 2001; International Labour Organization [ILO], 1998). Others fear that elected governments are actually ceding some of their sovereignty to consumers through these systems. Clearly the shift to nongovernmental regulation focuses more attention on consumers (rather than on the state or unions) as the key constituent of monitoring and enforcement.

Some critics also argue that monitoring, when it is conducted by local NGOs, can impede unionization or "crowd out" the efforts of local workers organizations. Compa (2001) discusses several cases in Central America in which NGOs appear to be "supplanting the unions' role as worker representatives by discussing wages and working conditions with factory managers," a process that will actually help "powerful companies to avoid union organizing, enforceable collective agreements, and government regulation." Others on the ground in Central America disagree with this assessment, arguing conversely that NGO monitoring has supported several union campaigns in El Salvador and Guatemala (Quinteros, 2001). The Kukdong case in Mexico highlights the potential of a coordinated unionNGO, north-south strategy. Cooperation among local workers, the AFL-CIO, NGOs, student activists, and the WRC and FLA supported the formation of an independent union, the signing of a new contract with Korean management, and important gains in pay and health and safety conditions (Brown, 2001). The spot- 
light of monitoring was useful in this case in protecting fledgling union organizing. Nonetheless, the debate in Central America underscores the reality that NGOs and unions continue to be "wary allies" and need to develop better means to work together to advance nongovernmental regulatory mechanisms (Compa, 2001).

A number of critics have also noted that codes and monitoring can hurt workers (Esbenshade, 2001; Liubicic, 1998). Monitoring reports can lead firms to cut contracts with poor performing factories, leading to job losses. Firms may reduce overtime at a factory working beyond a code of conduct's limit, despite workers needing these wages to survive. Workers may also be punished after complaining to auditors, as these systems often have limited protections for workers who complain. Even when monitoring is effective, some of the most hazardous jobs may be shifted further down the supply chain or into the informal sector to avoid the selective gaze of nongovernmental regulation.

There are also many problematic versions of nongovernmental regulation. For example, Global Social Compliance (formerly PricewaterhouseCoopers), a monitor for many large multinationals, depends largely on data provided by management and conducts very cursory inspections of factories. Worker interviews are conducted inside the factories. Factory managers know who is being interviewed, for how long, and on what issues (O'Rourke, 2002). This kind of monitoring can divert attention from the real issues in a factory, provide a false impression of performance, certify that a company is "sweat-free" based on very limited evidence, and actually disempower the workers it is meant to help. Although there is no single perfect way to monitor a factory, there are clearly better and worse monitoring practices.

\section{Conclusions}

New nongovernmental regulatory systems hold out both potential and peril. They offer the potential of opening up and strengthening regulatory systems and bringing in new voices and mechanisms for motivating improvements in global supply chains. They also harbor the peril of privatizing regulation, effectively closing off democratic forms of regulation and bypassing local governance.

Questions thus remain on how to move these systems toward more credible and complete global regulation. Can these systems be implemented beyond the first tier of suppliers? Can improved practices "spill over" into firms not directly tied to high-end global supply chains? Can southern stakeholders be brought into discussions and have a real say in the structure and implementation of these programs? Can mechanisms of representation and democracy be formalized in these nongovernmental systems? Can these systems provide workers and their advocates real tools that will increase their space for organizing? Is it possible to move towards interoperable systems of standards and monitoring? Can the ILO be brought more fully into nongovernmental regulation? And ultimately, can these new forms of regulation be designed to complement and support existing regula- 
tory processes and to directly benefit workers and poor communities around the world?

In some regards, the distinctions among these systems are beginning to break down. There is some convergence underway in codes and monitoring regimes that is blurring the categories presented in this article. Factory monitoring sometimes includes union officials. Supply chain monitoring is employing NGOs to monitor factories. And NGO investigations are sometimes coordinated with powerful brands. Nonetheless, there are still critical distinctions among these initiatives on issues such as the roles of workers and advocacy organizations, transparency of results, and strategies for remediation of problems.

And there is certainly no guarantee that voluntary codes of conduct and monitoring schemes will naturally converge on more complete or democratic systems of regulation. They are just as likely to diverge into a plethora of initiatives competing for the hearts and minds of consumers, serving to only confuse the public and undermine the credibility of nongovernmental initiatives. However, with strategic policies and coordinated efforts, nongovernmental regulation could instead move towards more credible, transparent, and accountable systems. Organizations implementing monitoring systems should commit, at a minimum, to making public their factory audits and auditing methodologies.

Another potentially promising avenue forward would involve efforts to build complementarity and interoperability among these systems. The different models of nongovernmental regulation are effective at different aspects of regulation. Factory monitoring identifies willing factories and gives managers information to support change. Supply-chain monitoring helps move standards down outsourced chains of production and provides brands with information to better manage their suppliers. Independent investigations help to expose the worst actors, provide information to workers, and create incentives for brands to prevent problems in their contractors. Connecting these initiatives in some interoperable way might help to overcome the challenges of access, scope, and credibility.

Already, several of these initiatives have worked together to resolve specific factory complaints. However, much more could be done to expand the complementarity and interoperability of these initiatives. As Fung, O'Rourke, and Sabel (2001) have argued, it is possible to build on the core dynamics of nongovernmental regulatory systems by first expanding the transparency of monitoring methods and results and then creating mechanisms to compare and benchmark the performance of manufacturing facilities and monitors. Increased transparency and comparison would allow stakeholders to evaluate individual factoriescomparing an FLA factory to a WRAP factory to an SAI factory-and then to compare monitors and monitoring methods to evaluate the effectiveness and credibility of monitoring protocols. This would provide important information on best practices in both monitoring and factory management; support a broad public dialogue on labor standards, monitoring, and enforcement; and build the credibility of these nongovernmental initiatives. 
Each of the emerging nongovernmental regulatory systems has clear weaknesses and challenges. Nonetheless, under certain conditions, nongovernmental regulation can influence factory labor practices. With increased transparency, improved technical capacities, and new mechanisms of accountability to workers and consumers, nongovernmental monitoring could complement existing state regulatory systems. As they develop, new nongovernmental regulatory systems should be evaluated along a number of criteria: (1) legitimacy — are key stakeholders involved in all stages of standard setting, monitoring, and enforcement?; (2) rigor-do codes of conduct meet or exceed ILO conventions and local laws, are standards measurable, and is monitoring technically competent?; (3) accountability-is monitoring independent and transparent?; (4) complementarity-do nongovernmental regulatory systems support state regulation and processes to learn and improve standards and monitoring methods?

Regulation in the global economy remains a daunting challenge. If these experiments in nongovernmental regulation can be made more transparent, accountable, and democratic, it may be possible to build outsourced regulation into an important response to the adverse impacts of globalization. At a minimum, nongovernmental regulation offers a glimpse of emerging strategies to regulate global supply chains and to begin the process of building new systems of governance over a fast-changing world.

Dara O'Rourke is an assistant professor in the Division of Society and Environment in the Department of Environmental Science, Policy, and Management at the University of California, Berkeley. Recent publications include Can We Put an End to Sweatshops? (Beacon Press 2001, with Archon Fung and Chuck Sabel) and Community-Driven Regulation: Balancing Development and the Environment in Vietnam (MIT Press, forthcoming).

\section{Acknowledgments}

I want to acknowledge Sharon Chan for research assistance and Garrett Brown, Archon Fung, Bob Jeffcott, Richard Locke, Katie Quan, Judith Tendler, and Lynda Yanz for comments on an earlier draft of this article.

\section{Notes}

1. For comparisons of company codes, see van Tulder and Kolk (2001) or company web pages such as www.nikebiz.com and www.gapinc.com.

2. As Nadvi and Wältring (2001, p. 34) note, "Despite the toothless nature of core labour standards, they have become a model for private social standards."

3. Private, for-profit monitors include PricewaterhouseCoopers (recently spun off as Global Social Compliance), Cal-Safety Compliance Corporation (CSCC), International Certification Services (SGS-ICS), Det Norske Veritas (DNV), Bureau Veritas Quality International (BVQI), Intertek Testing Service (ITS), Merchandise Testing Labs (MTL), MFQ, Sandler \& Travis (STR), Centro per l'Innovzione e lo Sviluppo Economico (CISE), RWTUV (Rheinisch-Westfalischer Technischer 
Uberwachungverein) Far East Thailand, Global Standards-Toan Tin Vietnam, and KPMG. Nonprofit groups include the U.S. NGO Verité, the Guatemalan Commission for the Monitoring of Code of Conduct (COVERCO), the Independent Monitoring Group of El Salvador (GMIES), Phulki (a Bangladeshi NGO), and the Honduran Independent Monitoring Team (EMI).

4. FLA members include Nike, Reebok, Liz Claiborne, Patagonia, Nordstrom's, adidas, Eddie Bauer, Polo Ralph Lauren, L. L. Bean, Nicole Miller, Phillips Van-Heusen, the Lawyers Committee for Human Rights, the International Labor Rights Fund, the RFK Memorial Center for Human Rights, and the National Consumers League. Notably, several union and NGO members of the original AIP left the organization when it evolved into the FLA in protest of what they believed were insurmountable flaws in the organization and its monitoring procedures.

5. The FLA has to date accredited 14 organizations to carry out this "external" monitoring. Each of these monitors is accredited to inspect factories in specific countries. These include A\&L Group, Cal Safety Compliance Corporation, Cotecna Inspections, COVERCO, Global Social Compliance (formerly PwC), Global Standards/Toan Tin, Intertek Testing Services, Kenan Institute Asia, LIFTStandards, Merchandise Testing Labs Brand Integrity, Phulki, SGS, T-Group Solutions, and Verite. As of June 2002, 982 companies had applied for certification, the majority of which were small university licensees.

6. Member organizations include Amana, Avon Products, Cutter and Buck, Dole Food, Eileen Fisher, Otto Versand, Toys R Us, and the UN Office of Project Services.

7. These include the Kukdong garment factory in Puebla, Mexico; the New Era baseball cap factory in Buffalo, New York; the BJ\&B cap factory in the Dominican Republic; and, the PT Dada apparel and stuffed toy factory in Indonesia. These investigations have involved six to eight people for 5 to 6 days each.

8. Phil Knight, the CEO of Nike Inc., withdrew a planned $\$ 30$ million donation to the University of Oregon after the university joined the WRC.

9. As one retailer in the ETI commented, "I can know my supply chain at 9 A.M., then by 10 A.M. it's all different" (Ethical Trading Initiative, 2001).

\section{References}

Arthurs, H. (2001). Reinventing labor law for the global economy: The Benjamin Aaron lecture. Berkeley Journal of Employment and Labor Law, 22(2), 271-294.

Ayres, I., \& Braithwaite, J. (1992). Responsive regulation: Transcending the deregulation debate. Oxford, United Kingdom: Oxford University Press.

Bartley, T. (2001, August). The professionalization of scrutiny: The rise of labor-standards monitoring organizations. Paper presented at conference of the American Sociological Association. Anaheim, CA.

Benjamin, M. (1998). What's fair about the Fair Labor Association (FLA)? Sweatshop Watch. Retrieved from http://www.sweatshopwatch.org/swatch/headlines/1998/gex_fla.html

Bernstein, A. (2001, November 19). Do-it-yourself labor standards: While the WTO dickers, companies are writing the rules. Business Week, 74.

Block, R., Roberts, K., Ozeki, C., \& Roomkin, M. (2001, April). Models of international labor standards. Industrial Relations, 40(2), 258-292.

Braithwaite, J., \& Drahos, P. (2000). Global business regulation. Cambridge, United Kingdom: Cambridge University Press.

Brown, G. (2001, Fall). Maquiladora Health and Safety Support Network Newsletter. Berkeley, CA.

Cashore, B. (2002). Legitimacy and the privatization of environmental governance: How non state market-driven (NSMD) governance systems gain rule making authority. Governance, 15(4), 503-529.

Chan, A. (2001). China's workers under assault-The exploitation of labor in a globalizing economy. Armonk, NY: M.E. Sharpe. 
Compa, L. (2001, July 2). Wary allies. American Prospect, 12(12), pp. 8-9.

Compa, L., \& Hinchliffe-Darricarrere, T. (1995). Enforcing international labor rights through corporate codes of conduct. Columbia Journal of Transnational Law, 33, 663.

Connor, T. (2001a). Still waiting for Nike to do it: Nike's labor practices in the three years since CEO Phil Knight's speech to the National Press Club. San Francisco: Global Exchange. Retrieved from http://www.globalexchange.org/economy/corporations/nike/

Conroy, M. (2001). Can advocacy-led certification systems transform global corporate practices? Evidence and some theory (Working Paper Series No. 21). Amherst, MA: Political Economy Research Institute, University of Massachusetts.

Cutler, C., Haufler, V., \& Porter, T. (1999). Private authority in international politics. Albany: State University of New York Press.

Diller, J. (1999). A social conscience in the global marketplace? Labour dimensions of codes of conduct, social labeling, and investor initiatives. International Labour Review, 138(2), 99-130.

Douglas, W. (2001). Who's who in codes of conduct. New Economy Information Service. Retrieved from http://www.newecon.org/global/trade/CodesofConductDouglas-01-02-01.html\#enforcing

Elliott, K., \& Freeman, R. (2001, January). White hats or Don Quixotes? Human rights vigilantes in the global economy (NBER (National Bureau of Economic Research) Working Paper No. W8102). Cambridge, MA.

Environics International. (1999, May). The millenium poll on corporate social responsibility. Retrieved from www.environicsinternational.com

Esbenshade, J. (2000, August). Globalization and resistance in the apparel industry: The struggle over monitoring. Paper presented at the meeting of the American Sociological Association, Washington, DC.

Esbenshade, J. (2001, Spring). The social accountability contract: Private monitoring from Los Angeles to the global apparel industry. Labor Studies Journal, 26(1), 98-120.

Ethical Trading Initiative (ETI). (2001). Learning our trade [Annual Report 2000-01]. London: Author.

Evans, P. (1997). The eclipse of the state? Reflections on stateness in an era of globalization. World Politics, 50, 1.

Fair Labor Association (FLA). (2002, April 28). New changes to increase the transparency, independence, and scope of the FLA [Press release].

Freeman, R. (1994). A hard-headed look at labour standards. In W. Sengenberger \& D. Campbell (Eds.), International Labour Standards and Economic Interdependence. Geneva: International Labour Organization, 79-92.

Fung, A., O'Rourke, D., \& Sabel, C. (2001). Can we put an end to sweatshops? Boston: Beacon Press.

Gereffi, G., Garcia-Johnson, R., \& Sasser, E. (2001, July-August). The NGO-industrial complex. Foreign Policy, 125, 56-65.

Global Compact (2001). Overview Retrieved from www.unglobal compact.org.

Haufler, V. (2001). A public role for the private sector: Industry self-regulation in a global economy. Washington, DC: Carnegie Endowment for International Peace.

Herrnstadt, O. (2001). Voluntary corporate codes of conduct: What's missing. Labor Lawyer, 16, 349-370.

Hughes, S., \& Wilkinson, R. (1998). International labour standards and world trade: No role for the World Trade Organization? New Political Economy, 3, 375-389.

International Labour Organization (ILO). (1998). Overview of global developments and office activities concerning codes of conduct, social labelling, and other private sector initiatives addressing labour issues. Geneva, Switzerland: Author.

Jeffcott, B., \& Yanz, L. (1999, October 18). Voluntary codes of conduct: Do they strengthen or undermine government regulation and worker organizing. Maquila Solidarity Network. Retrieved from www.maquilasolidarity.org/resources/codes/volcodes $99 . h t m$ 
Justice, D. (2001). The new codes of conduct and the social partners. International Confederation of Free Trade Unions. Retrieved from http://www.icftu.org/

Knill, C., \& Lehmkuhl, D. (2002). Private actors and the state: Internationalization and changing patterns of governance. Governance, 15(1), 44-63.

Labor Rights in China (LARIC). (1999). No illusions: Against the global cosmetic SA8000. Hong Kong: Author.

Lee, E. (1997). Globalization and labour standards: A review of issues. International Labour Review, 136(2), 173-189.

Lipschutz, R. (2000, December). Regulation for the rest of us? Global civil society, social regulation, and national impacts. Paper prepared for workshop on Human Rights and Globalization, University of California-Santa Cruz.

Liubicic, R. (1998). Corporate codes of conduct and product labeling schemes: The limits and possibilities of promoting international labor rights through private initiatives. Law and Policy in International Business, 30(1), 111-158.

Maquila Solidarity Network (MSN). (2001a, September). The changing terrain in the codes of conduct debate. Retrieved from http://www.maquilasolidarity.org/

Maquila Solidarity Network (MSN). (2001b). Codes update (Issues no. 3-9). Retrieved from http://www.maquilasolidarity.org/resources/codes/

Maquila Solidarity Network (MSN). (2002). Codes update (Issue no. 12)., Retrieved from http://www.maquilasolidarity.org/resources/codes/memo12.htm

Maskus, K. (1997). Should core labor standards be imposed through international trade policy (World Bank Development Research Group Policy Research Working Paper no. 1817), World Bank, Washington, D.C.

McCubbins, M., \& Schwartz, T. (1984). Congressional oversight overlooked: Police patrols versus fire alarms. American Journal of Political Science, 28, 165-79.

Nadvi, K., \& Kazmi, S. (2001). Global standards and local responses (Working Paper). Sussex, United Kingdom: Institute for Development Studies.

Nadvi, K., \& Wältring, F. (2001). Making sense of global standards (Draft IDS-INEP working paper). Sussex, United Kingdom: Institute for Development Studies.

Nike (2002). Management of Environment, Safety, and Health (MESH). Retrieved from www.nikebiz.com/labor/mesh.shtml.

Nike refuses to comply with WRC, cancels U. contract. (2000, April 3). Brown Daily Herald, Retrieved from www.browndailyherald.com.

Organisation for Economic Cooperation and Development (OECD). (1999). Codes of corporate conduct: An inventory. Paris: Trade Directorate.

O'Rourke, D. (2002). Monitoring the monitors: A critique of corporate third-party labor monitoring. In R. Jenkins, R. Pearson, \& G. Seyfang (Eds.), Corporate responsibility and labour eights: Codes of conduct in the global economy. London: Earthscan, 196-208.

Pearson, R., \& Seyfang, G. (2002). Codes of conduct as enclave social policy. In R. Jenkins, R. Pearson, \& G. Seyfang (Eds.), Corporate responsibility and labour eights: codes of conduct in the global economy. London: Earthscan.

Quinteros, C. (2001, October). Independent monitoring seen from the Central American region. Paper prepared for the SOMO Conference: From Codes to Compliance, Brussels, Belgium.

Reinicke, W. (1998). Global public policy: Governing without government? Washington, DC: Brookings Institution Press.

Sabel, C. (1994). Learning by monitoring: The institutions of economic development. In N. Smelser \& R. Swedberg (Eds.), Handbook of Economic Sociology (pp. 137-165). Princeton, NJ: Princeton-Sage.

Schmidt, V. (1995). The new world order incorporated: The rise of business and the decline of the nation state. Daedalus, 124(2), 75-106. 
Strange, S. (1996). The Retreat of the State. Cambridge, United Kingdom: Cambridge University Press.

Teubner, G. (1983). Substantive and reflexive elements in modern law. Law and Society Review, 17, 239-285.

Utting, P. (2002). Regulating business via multistakeholder initiatives: A preliminary assessment, in P. Utting (ed), Voluntary Approaches to Corporate Responsibility. Geneva, Switzerland: United Nations Non-Governmental Liaison Service, 61-130.

van Tulder, R., \& Kolk, A. (2001). Multinationality and Corporate Ethics: Codes of Conduct in the Sporting Goods Industry. Journal of International Business Studies, 32(2), 267-283.

Varley, P. (1998). The Sweatshop Quandry: Corporate Responsibility on the Global Frontier, Washington, D.C. \& Investor Responsibility Research Center.

Wach, H., \& Nadvi, K. (2000). Global Labour and Social Standards and their Implications for Developing Country Producers: A Bibliographic Overview (Working paper). Sussex: United Kingdom: Institute for Development Studies.

Wick, I. (2001). Workers' Tool or PR Ploy? A Guide to Codes of International Labour Practice. Bonn, Germany: Friedrich-Ebert-Stiftung. 